\title{
AN EXPLORATORY EVALUATION OF THE PULPABILITY OF Brachystegia spiciformis AND Pericopsis angolensis FROM THE ANGOLAN MIOMBO WOODLANDS
}

\author{
Lino Manuel Vicente Sangumbe ${ }^{1,2,3}$, Miguel Pereira $^{4}$, Isabel Carrillo ${ }^{1,2}$, \\ Regis Teixeira Mendonça ${ }^{1,2, \star}$
}

\begin{abstract}
Brachystegia spiciformis and Pericopsis angolensis are two hardwood species found in the Miombo woodlands. The wood features, kraft pulping and strength pulp properties of both species were evaluated in order to determine their potential as raw material for papermaking. Brachystegia spiciformis wood density was $640 \mathrm{~kg} \mathrm{~m}^{-3}$ and Pericopsis angolensis was 795 $\mathrm{kg} \mathrm{m}^{-3}$. Pericopsis angolensis wood has higher cell wall thickness and occluded fibre lumen as remarkable anatomical properties. Runkel ratio, slenderness ratio, and the coefficients of flexibility and rigidity in Brachystegia spiciformis were 1,5; 65,7; 41,2\% and 29,4\% while in Pericopsis angolensis these values were 17,$6 ; 59,9 ; 5,4 \%$ and 47,3\%, respectively. Brachystegia spiciformis has a higher cellulose content, lower hemicellulose and lignin content, and higher $\mathrm{S} / \mathrm{G}$ ratio than Pericopsis angolensis. In kraft pulping, a higher demand of active alkali was needed for both species, and pulps with high kappa number (24-27) and low pulp yield (40\%) were obtained. Pericopsis angolensis pulps reached tensile, tear and burst indexes of 99,6 $\mathrm{Nm} \mathrm{g}^{-1} ; 5,9 \mathrm{mN} \cdot \mathrm{m}^{2} \mathrm{~g}^{-1}$ and 4,9 $\mathrm{kPa} \cdot \mathrm{m}^{2} \mathrm{~g}^{-1}$, respectively. Brachystegia spiciformis pulps reached tensile, tear and burst indexes of $100,3 \mathrm{Nm} \mathrm{g}^{-1} ; 10,7 \mathrm{mN} \cdot \mathrm{m}^{2} \mathrm{~g}^{-1}$ and 6,1 $\mathrm{kPa} \cdot \mathrm{m}^{2} \mathrm{~g}^{-1}$, respectively. As a conclusion, Brachystegia spiciformis wood has better pulpability than Pericopsis angolensis wood, according to its pulps properties, despite of the similar pulp yield between both species. Both species may be suitable for unbleached wrapping papers and rigid cardboards manufacturing.
\end{abstract}

Keywords: Derived wood properties, kraft pulping, strength properties, wood anatomy, wood chemistry.

\section{INTRODUCTION}

Brachystegia spiciformis and Pericopsis angolensis are two hardwood species from the Miombo woodlands (formation of natural forest, dry and warm predominantly in the South-Central region of Africa). In Angola, this forest occupies an area of $585949 \mathrm{~km}^{2}$, which corresponds to $47 \%$ of the total country area, being considered mainly as a source for timber production (Figueiredo et al. 2009, Sangumbe and Pereira 2014). The wood of B. spiciformis is moderately heavy, slightly hard

\footnotetext{
${ }^{1}$ Laboratorio de Recursos Renovables, Centro de Biotecnología, Universidad de Concepción, Concepción, Chile.

${ }^{2}$ Facultad de Ciencias Forestales, Universidad de Concepción, Concepción, Chile.

${ }^{3}$ Faculdade de Ciências Agrarias, Universidade José Eduardo dos Santos, Huambo, Angola.

${ }^{4}$ Laboratorio de Productos Forestales, Facultad de Ingeniería, Universidad de Concepción, Concepción, Chile.

•Corresponding author: rteixeira@udec.cl

Received: 25.01.2017 Accepted: 28.11.2017
} 
and difficult to be worked, with no significant difference between heartwood and sapwood colours; while $P$. angolensis wood is very heavy and hard, the heartwood is coloured green-brown and the sapwood is grey-yellow (Frost 1996, Palgrave 2002). The wood of B. spiciformis and P. angolensis are used for construction, cheap furniture, railway sleepers, utensils and beehives. It is suitable for flooring, joinery, mine props, vehicle bodies, crates, veneer and plywood. It is equally important as a source of firewood and charcoal, being among the preferred species for charcoal making throughout Southern Africa (Louppe et al. 2008). For another applications of P. angolensis wood, Uetimane et al. (2009) studied its anatomical properties in order to facilitate the introduction of the specie to the wood industry; Lhate et al. (2010) determine the chemical composition and relate it to wood durability and machining properties; while Cuvilas et al. (2014) made an evaluation of its wood properties to determine its quality as fuel. Regarding $B$. spiciformis investigations, there are some related species reports available. Atuanya and Ibhadode (2011) evaluated the chemical composition, microstructure and thermal behavior of Brachystegia nigerica to determine its potential as reinforcement for polymer composites. Other studies have reported the yield and strength properties of $B$. nigerica veneer products (Olufemi 2012), evaluations about the ethanol production from Brachystegia eurycoma have been made (Afe 2016a, Afe 2016b), and also assessments of the acoustic properties of B. eurycoma talking drums (Noah et al. 2014).

In Angola, the production of pulp and paper dated back to 1950-1960, where plantations of Eucalyptus, Pinus and Cupressus species were established as fibre source for the national cellulose mill (Companhia de Celulose do Ultramar Português, CCUP) (Silva 1971, Delgado-Matas and Pukkala 2012). After the 1975 independence, 27 years of civil war struck the country, and an extensive illegal logging of the forests occurred due to the lack of fuel sources, in addition to forest fires that destroyed most of the stablished plantations (Delgado-Matas and Pukkala 2012). However, the forestry activities were relaunched in the 2010's, with the beginning of the rehabilitation of the industrial segments related to the pulp and paper production chains (MINADERP 2011). As a consequence, the knowledge of the Angolan Miombo species needs to be assessed, as well as, the potential industrial application of wood from these species for chemical conversion processes (pulping, cellulose derivatives, among others). This study is aimed to evaluate the characteristics of the wood, kraft pulping and strength pulp properties of $B$. spiciformis and $P$. angolensis and their potential as raw material for papermaking.

\section{EXPERIMENTAL}

\section{Site and sampling}

Samples of Brachystegia spiciformis Benth and Pericopsis angolensis (Baker) Meeuwen were obtained in Sambo, Angola, located at an altitude of $1704 \mathrm{~m}$ above sea $\left(13^{\circ} 15^{\prime} 53,61^{\prime \prime} \mathrm{S}\right.$ and $\left.16^{\circ} 03^{\prime} 52,28^{\prime \prime} \mathrm{E}\right)$. The soil is ferrallitic with sandy loam and $\mathrm{pH} 4,5$. The climate is humid with temperate seasons. The annual rainfall ranging from 1100 to $1400 \mathrm{~mm}$, the average of annual temperature is $20^{\circ} \mathrm{C}$ and annual relative humidity is 60 to $70 \%$. From one tree of each species (dominant and with straight form) $40 \mathrm{~cm}$ logs were taken at $2,5 \mathrm{~m}$ from the base of the tree. The age of the specimens was approximately 24 years old for $B$. spiciformis and 40 years old for $P$. angolensis.

\section{Wood material}

Logs obtained at 2,5 $\mathrm{m}$ of height were cut in 3-4 cm thickness disks. From the disks of each species $3,0 \times 2,5 \times 0,2 \mathrm{~cm}$ wood chips where handmade for pulping procedures. A fraction of the chips was also milled in a knife mill and sieved to $45 / 60$ mesh for chemical analysis. For wood quality analysis, sapwood and heartwood sections where manually separated from the disks and wood blocks of $2 \mathrm{~cm}^{3}$ were taken at each section. 


\section{Anatomical characterization}

\section{Basic density determination}

Wood blocks from sapwood and heartwood of each species were used to determine basic density according to the T258 om-94. Basic density is the ratio of oven dry weight by the green volume, expressed in terms of weight per unit volume. The basic density of wood was calculated according to Heinrichs and Lassen (1970). Basic density measurements of each sample were done in triplicate.

\section{Transversal anatomical characterization}

Sapwood and heartwood blocks were macerated with distilled water and glycerine for 7 days. From each block, transversal micro-sections of $30 \mu \mathrm{m}$ thickness were obtained using a sliding microtome (MICROM H325). Samples were stained with Safranin and Astra blue, dehydrated with ethanol and assembled in a slide using Canada balsam. Images were obtained using a Zeiss microscope (Primo Star) connected to a personal computer and a digital camera (Canon A640) for image capture. Eighty fibres were randomly selected and their cell wall thickness, fibre width and lumen width were measured with a 100x total magnification. Moreover, eighty vessels randomly selected were measured with a 10x magnification for vessel width and mean vessel area determination. From the captures of 10x magnification the average vessel coverage was also determined, corresponding to the percentage of cross-sectional area covered by vessels. All these parameters were measured using AxioVision Software (Zeiss), which had the proper calibration for each capture lens. Similar procedure was used by Aguayo et al. (2010).

\section{Fibre quality analysis}

Samples of $0,1 \times 0,1 \times 0,5 \mathrm{~cm}$ were obtained from wood chips. Wood samples were macerated in water and treated using Franklin solution (30\% hydrogen peroxide and acetic acid, $\left.1: 1 \mathrm{v} \mathrm{v}^{-1}\right)$ for $8 \mathrm{~h}$ at $70^{\circ} \mathrm{C}$. The solution was decanted and the remaining fibrous material was washed with water until a neutral $\mathrm{pH}$ was achieved. Average fibre length, fibre width, fines content, and coarseness (defined as fibre mass per fibre length) were determined using L\&W Fiber Tester equipment (Lorentzen \& Wettre, Sweden). L\&W Fiber Tester is an instrument for advanced analysis of fibre dimensions. It has a sample feeder where the pulp sample is introduced to the equipment as a suspension for two-dimensional imaging analysis. It consists in two plates that allow the fibres to move freely in two dimensions where a camera captures fibre images for dimension measurements. $200 \mathrm{mg}$ of sample were previously disaggregated in $200 \mathrm{~mL}$ of distilled water for $10 \mathrm{~min}$. During the analysis of this suspension, the equipment was set to measure approximately 35000 fibres of each sample, setting as fines to elements of 0 to $0,2 \mathrm{~mm}$ of length to ensure that broken fibres and fines are not included in the final averages of fibre measurements. Each sample was analyzed in duplicate.

\section{Derived values of wood fibres}

Derived wood properties were calculated from measurements of fibre morphology (Runkel 1949, Luce 1970, Wangaard 1962, Istas et al. 1954, Hus et al. 1975):

Runkel ratio $=(2 \times$ Cell wall thickness $) /$ lumen width

Luce's shape factor $=\left(\right.$ fibre widht ${ }^{2}-$ lumen width $\left.^{2}\right) /\left(\right.$ fibre width ${ }^{2}+$ lumen width $\left.{ }^{2}\right)$

Slenderness ratio $=$ fibre length $/$ fibre width

Flexibility coefficient $(\%)=($ lumen width $/$ fibre width $) \times 100$

Rigidity coefficient $(\%)=($ cell wall thickness $/$ fibre width $) \times 100$

\section{Chemical composition of wood}

\section{Lignin content}

Two grams of milled wood samples were extracted with $90 \%$ acetone for $16 \mathrm{~h}$. Samples were characterized for lignin by acid hydrolysis following the methodology described by Mendonça et al. 
(2008). In a test tube were weighed $300 \mathrm{mg}$ of sample and added $3 \mathrm{~mL}$ of $72 \%\left(\mathrm{w} \mathrm{w}^{-1}\right) \mathrm{H}_{2} \mathrm{SO}_{4}$. The hydrolysis was carried out in a water bath at $30^{\circ} \mathrm{C}$ for $1 \mathrm{~h}$ with a glass-rod shaking every 10 min. Later, the acid was diluted to $4 \%\left(\mathrm{w} \mathrm{w}^{-1}\right)$ with $84 \mathrm{~mL}$ of distilled water and the mixture transferred to a $250-\mathrm{mL}$ Erlenmeyer flask and autoclaved for $1 \mathrm{~h}$ at $121^{\circ} \mathrm{C}$ (post-hydrolysis). The residual material was cooled and filtered through a porous glass filter number 3. Solids were dried to constant weight at $105^{\circ} \mathrm{C}$ and determined as insoluble lignin. Soluble lignin was determined by measuring the absorbance of the solution at $205 \mathrm{~nm}$. Each sample was analyzed in triplicate.

\section{S/G ratio of lignin}

The determination of the $\mathrm{S} / \mathrm{G}$ ratio in the lignin of both species was determined by oxidation with copper (II) oxide carried out following the methodology described by Chen (1992). In an 80$\mathrm{mL}$ stainless steel reactor it was added $400 \mathrm{mg}$ of sample (milled and extracted wood), $2 \mathrm{~g} \mathrm{CuO}, 15$ $\mathrm{mL} \mathrm{NaOH} 2 \mathrm{M}$ and $100 \mathrm{mg} \mathrm{Fe}\left(\mathrm{NH}_{4}\right)_{2}\left(\mathrm{SO}_{4}\right)_{2} \cdot 6 \mathrm{H}_{2} \mathrm{O}$. Nitrogen was bubbled inside the reactor which was tightly closed and immersed in an oil bath for $3 \mathrm{~h}$ at $170^{\circ} \mathrm{C}$. After the reaction, it was added to the reactor $10 \mathrm{~mL} \mathrm{NaOH} 1 \mathrm{M}$ and $10 \mathrm{~mL}$ of distilled water. The mixture was acidified to $\mathrm{pH} 1$ with $\mathrm{HCl}$. The content of the reactor was transferred to a centrifuge tube and centrifuged at $2500 \mathrm{rpm}$ for $10 \mathrm{~min}$. The liquid fraction was collected, transferred to a separation funnel and extracted three times with $50 \mathrm{~mL}$ of diethyl ether. The organic fraction was further evaporated $\left(40^{\circ} \mathrm{C}\right)$ at reduced pressure (450 mbar). The solid residue was dissolved in $1 \mathrm{~mL}$ pyridine and $0,5 \mathrm{~mL}$ of sample was silylated with $0,5 \mathrm{~mL}$ BSTFA. Derivatization products were quantified by GC/FID using the conditions published elsewhere. The amount of syringyl (S) units was the sum of syringaldehyde and syringic acid; and the amount of guaiacyl $(\mathrm{G})$ units was the sum of vanillin and vanillic acid. The amount of S compounds was divided by the amount of $\mathrm{G}$ compounds to determine the $\mathrm{S} / \mathrm{G}$ ratio in lignin. Each sample was analyzed in triplicate.

\section{Cellulose and hemicelluloses determination}

The content of cellulose was performed following the Kûrshner-Höffer method, occupied by Carballo et al. (2004). On 0,15 g of extractive-free milled wood, $25 \mathrm{~mL}$ reactive mixture of $\mathrm{HNO}_{3}: \mathrm{C}_{2} \mathrm{H}_{6} \mathrm{O}(1: 4)$ was refluxed in a water bath for $1 \mathrm{~h}$, decanted and a new amount of reaction mixture was added, repeating this operation three times, subsequently, $25 \mathrm{~mL}$ of $1 \% \mathrm{KOH}$ was added for $30 \mathrm{~min}$, the residual material was filtered through porous glass filter number 2 . Solids were dried to constant weight at $105^{\circ} \mathrm{C}$ and determined as wood cellulose. Each sample was analyzed in triplicate. The hemicelluloses were quantified by acid methanolysis according Sundberg et al. (1996). Extractive free wood meal was freeze dried prior to weighing $10 \mathrm{mg}$ into a pear-shaped flask. Samples were subjected to acid methanolysis by the addition of $2 \mathrm{~mL}$ of $2 \mathrm{M}$ solution of $\mathrm{HCl}$ in anhydrous methanol. Samples were kept in an oven at $100^{\circ} \mathrm{C}$ for $3 \mathrm{~h}$. After cooling to room temperature, $100 \mu \mathrm{L}$ of pyridine was added to neutralize the acidic solution as well as $4 \mathrm{~mL}$ of methanol (containing sorbitol at $0,1 \mathrm{mg} /$ $\mathrm{mL}$ as an internal standard). To avoid fibres during silylation, $1 \mathrm{~mL}$ of the clear sample solution was transferred into another pear-shaped flask and the solution reduced by rotary evaporation at $40^{\circ} \mathrm{C}$. Samples were dissolved in $100 \mu \mathrm{L}$ pyridine. For silylation, $150 \mu \mathrm{L}$ hexamethyldisilazane (HMDS) and $80 \mu \mathrm{L}$ trimethylchlorosilane (TMCS) were added prior to thorough shaking of the sample. After $4 \mathrm{~h}$ at room temperature, samples were analysed by GC-FID. One $\mu \mathrm{L}$ of a silylated sample was injected via a split injector $\left(260^{\circ} \mathrm{C}\right.$, split ratio 1:20) into a $30 \mathrm{~m}$ x $0,25 \mathrm{~mm}$ i.d. x $0,25 \mu \mathrm{m}$ film thickness column DB5. The column temperature program was $100^{\circ} \mathrm{C}$ to $175^{\circ} \mathrm{C}\left(4^{\circ} \mathrm{C} \mathrm{min}{ }^{-1}\right)$ followed by $175^{\circ} \mathrm{C}$ to $290^{\circ} \mathrm{C}\left(12^{\circ} \mathrm{C}\right.$ $\mathrm{min}^{-1}$ ). The detector (FID) temperature was $290^{\circ} \mathrm{C}$. Nitrogen was used as carrier gas. Different peaks were identified by analysing acid methanolysis products of analytical grade sugars (arabinose, xylose, galactose, glucose, mannose, rhamnose, glucuronic acid and galacturonic acid). Calibration curves and factors were determined for each sugar unit in order to calculate the concentration in the samples. Each sample was analyzed in triplicate.

\section{Holocellulose and alpha-cellulose contents}

Holocellulose content was determined in extractive-free wood using $250 \mathrm{mg}$ weighed into a $50-\mathrm{mL}$ flask where $5 \mathrm{~mL}$ of deionised water, $2 \mathrm{~mL}$ of glacial $\mathrm{CH}_{3} \mathrm{COOH}$ and $5 \mathrm{~mL}$ of $80 \% \mathrm{NaClO}_{2}$ were added. The flask was closed with a glass cap and was immersed in a water bath at $90^{\circ} \mathrm{C}$ for $1 \mathrm{~h}$. Subsequently, 
more $2 \mathrm{~mL}$ of glacial $\mathrm{CH}_{3} \mathrm{COOH}$ and $5 \mathrm{~mL}$ of $80 \% \mathrm{NaClO}_{2}$ were added to the flask, and the reaction was maintained for $1 \mathrm{~h}$ at $90^{\circ} \mathrm{C}$. The reaction was quenched by cooling the sample in a water bath at $10^{\circ} \mathrm{C}$. The solids were filtered through porous glass filter number 2 , washed with $500 \mathrm{~mL}$ of deionised water, dried at $105^{\circ} \mathrm{C}$ until constant weight and determined as holocellulose. To determine the alphacellulose content, $100 \mathrm{mg}$ of holocellulose were placed in a $25-\mathrm{mL}$ flask, which was treated with $8 \mathrm{~mL}$ $\mathrm{NaOH} 17,5 \%\left(\mathrm{w} \mathrm{v}^{-1}\right)$ for $30 \mathrm{~min}$ at room temperature with shaking every $10 \mathrm{~min}$. Then, $8 \mathrm{~mL}$ of distilled water was added to the solution and the reaction was carried out for another $30 \mathrm{~min}$. The solids were filtered; the sample was washed with $150 \mathrm{~mL}$ of distilled water and impregnated with $20 \mathrm{~mL}$ of $1 \mathrm{M}$ $\mathrm{CH}_{3} \mathrm{COOH}$ for $5 \mathrm{~min}$. The residue was washed with abundant distilled water and dried at $105^{\circ} \mathrm{C}$ until constant weight for the quantification of alpha-cellulose (Yokoyama et al. 2002). Each sample was analyzed in triplicate.

\section{Kraft pulping}

Kraft pulping was performed in a rotatory digester equipped with four independent $1,5-\mathrm{L}$ reactors (Regmed, Brazil). For each reaction, $100 \mathrm{~g}$ of wood chips (dry basis) and cooking liquor with active alkali (AA) concentrations from $14 \%$ to $25 \%$ and $30 \%$ sulfidity (both expressed in $\mathrm{NaOH}$ basis) was used. Heating time to the maximum temperature $\left(165^{\circ} \mathrm{C}\right)$ was $90 \mathrm{~min}$ and the $\mathrm{H}$-factor was 800 . The resulting material from each cooking was disintegrated and pulps were screened through a $0,2 \mathrm{~mm}$ slot screen. The pulp was centrifuged to $35 \%$ consistency and weighted. The exact moisture was determined and the screened pulp yield was calculated. Kappa number was determined according TAPPI T236 om-99. Strength properties were determined in unrefined and PFI-refined pulps (2500 and $5000 \mathrm{rpm})$ following TAPPI standard methods for sheet formation (T220 sp-00), tensile index (T404 om-92), tear index (T414 om-98) and burst index (T403 om-97).

\section{Data analysis}

Statistical analyses of chemical, anatomical and pulp properties were performed using the software SAS system 9.0 (SAS Institute). Unpaired t-test was used to compare the properties between species.

\section{RESULTS AND DISCUSSION}

\section{Anatomical characterization of wood}

Transversal micrographs showing the cellular anatomy of B. spiciformis wood are presented in Figure 1. It can be observed that the vessels are distributed regularly throughout the xylem and are surrounded by aliform axial parenchyma. However, the proportion of parenchyma surrounding the vessel elements is lower in sapwood (Figure 1A) than in heartwood (Figure 1B). It has been showed that the distribution of aliform and paratracheal axial parenchyma arranged as bands gives place to false rings, which also can be associated to the production of fibres with high cell wall thickness (Trouet et al. 2001, Grundy 2006). In Figure 1C and Figure 1D, it can be observed the fibre anatomy of sapwood and heartwood, where cell wall thickness is higher in sapwood than in heartwood fibres. It must be also noted that fibre and vessels differences from earlywood and latewood of a growth ring could not be detectable, which is in agreement with the studies that report difficulties to determine cross-dating by tree ring Brachystegia analysis (Trouet et al. 2001, Grundy 2006). This is probably due to the ability of the large root system to store water in the dry season (Grundy 2006). Regarding P. angolensis, it can be observed a diffuse distribution of vessels in sapwood (Figure 1E) and in heartwood (Figure 1F). However, in heartwood, a higher number of vessels are filled with extractives deposits. Fibre structure of sapwood (Figure 1G) and heartwood (Figure 1H) showed a high cell wall thickness with occluded fibre lumen in both sections. This feature could cause problems for impregnation and diffusion of reagents inside the lignocellulosic matrix during chemical treatments. Similar anatomical features have been reported by Ali et al. (2008) and Uetimane et al. (2009), who give a more detailed description of the arrangement of xylem cells in P. angolensis. Similar to B. spiciformis observation, earlywood and 
latewood in P. angolensis could not be detectable.

In Table 1 are presented the features of sapwood and heartwood from B. spiciformis and $P$. angolensis. The basic wood density of $B$. spiciformis and $P$. angolensis sapwood was higher than heartwood basic density, while wood basic density average for $B$. spiciformis was $640 \mathrm{~kg} \mathrm{~m}^{-3}$ and for P. angolensis was $795 \mathrm{~kg} \mathrm{~m}^{-3}$. For $P$. angolensis, it has been reported wood density values of $758 \mathrm{~kg}$ $\mathrm{m}^{-3}$ (Abbot and Lowore 1999), $865 \mathrm{~kg} \mathrm{~m}^{-3}$ (Ali et al. 2008), $941 \mathrm{~kg} \mathrm{~m}^{-3}$ (Uetimane et al. 2009), $920 \mathrm{~kg}$ $\mathrm{m}^{-3}$ (Lhate et al. 2010) and $865 \mathrm{~kg} \mathrm{~m}^{-3}$ (Cuvilas et al. 2014), which is in agreement with our results. Abbot and Lowore (1999) reported for B. spiciformis a wood density of $579 \mathrm{~kg} \mathrm{~m}^{-3}$, including also reports for Brachystegia boehmii with $598 \mathrm{~kg} \mathrm{~m}^{-3}$, Brachystegia utilis with $598 \mathrm{~kg} \mathrm{~m}^{-3}$, Brachystegia longifolia with $548 \mathrm{~kg} \mathrm{~m}^{-3}$ and Brachystegia floribunda with $676 \mathrm{~kg} \mathrm{~m}^{-3}$. Also, it was found reports for B. eurycoma with wood density of $600 \mathrm{~kg} \mathrm{~m}^{-3}$ (Afe 2016a) and $642 \mathrm{~kg} \mathrm{~m}^{-3}$ (Noah et al. 2014). All these findings are in agreement with the density value found in this study for B. spiciformis.

Fibre features showed higher values for cell wall thickness in sapwood from both species, being $P$. angolensis fibre cell walls thicker than B. spiciformis cell walls (Table 1). Lumen width is also different in heartwood and sapwood from both species, but $P$. angolensis lumen width is occluded as it was already mentioned. Fibre width showed no differences at the different sections of B. spiciformis, which is not the same behaviour for $P$. angolensis observations. Regarding vessels features, the area of vessels, vessel coverage and vessel width is higher in sapwood than in heartwood of both species; while $B$. spiciformis showed higher mean area of vessel and higher vessel width average than $P$. angolensis. The radial variation pattern of anatomical properties in hardwoods has been widely report. It is known that the size of vessels increases as cambial age increases (Hudson et al. 1998, Leal et al. 2003, Carrillo et al. 2015). Same pattern of increasing values from pith to bark is known for fibre width, cell wall thickness, fibre length, wood density and coarseness (Miranda and Pereira 2002, Ohshima et al. 2004, Quilhó et al. 2006, Ramírez et al. 2009, Carrillo et al. 2015). These assertions are in agreement with the results found for the sapwood section, close to the bark, and the heartwood section, close to the pith, in B. spiciformis and P. angolensis.

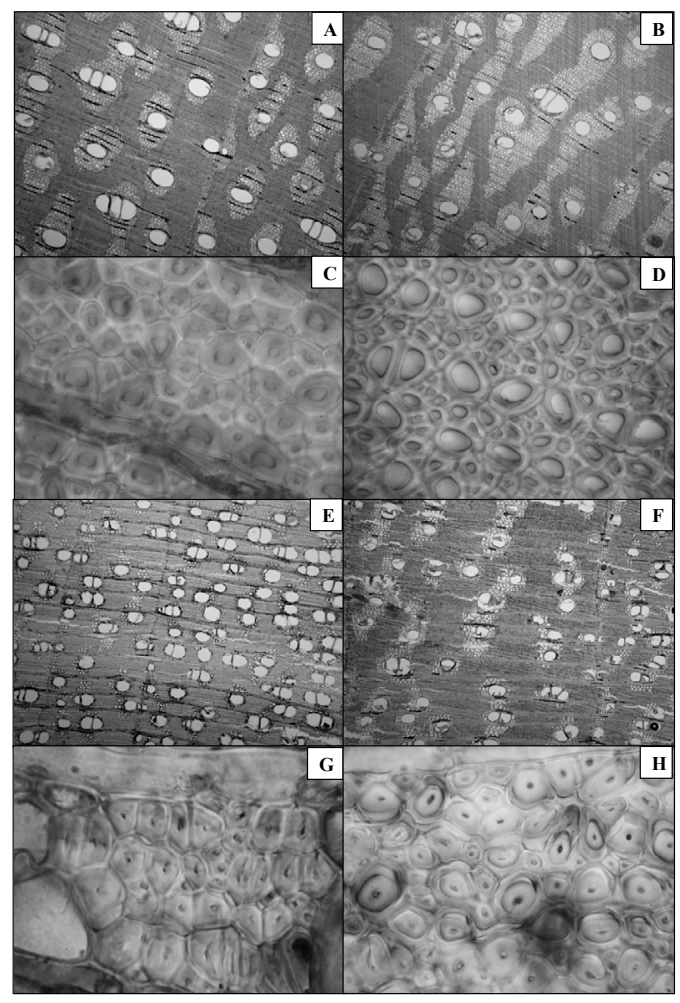

Figure 1. Transversal sections of B. spiciformis sapwood at $4 \mathrm{X}(\mathrm{A})$, heartwood at $4 \mathrm{X}(\mathrm{B})$, sapwood at 100X (C), heartwood at 100X (D) and P. angolensis sapwood at 4X (E), heartwood at 4X (F), sapwood at $100 \mathrm{X}(\mathrm{G})$, heartwood at $100 \mathrm{X}(\mathrm{H})$. 
Table 1. Anatomical features of sapwood and heartwood of B. spiciformis and P. angolensis.

\begin{tabular}{|c|c|c|c|c|}
\hline & \multicolumn{2}{|c|}{ B. spiciformis } & \multicolumn{2}{|c|}{ P. angolensis } \\
\hline & Heartwood & Sapwood & Heartwood & Sapwood \\
\hline \multirow{2}{*}{$\begin{array}{l}\text { Density } \\
\left(\mathrm{kg} \mathrm{m}^{-3}\right)\end{array}$} & $630^{\mathrm{b}}$ & $650^{\mathrm{a}}$ & $740^{\mathrm{b}}$ & $850^{\mathrm{a}}$ \\
\hline & \multicolumn{2}{|c|}{$640^{b} \pm 12$} & \multicolumn{2}{|c|}{$795^{a} \pm 64$} \\
\hline \multirow{2}{*}{$\begin{array}{l}\text { Fibre width } \\
\quad(\mu \mathrm{m})\end{array}$} & $13,68^{\mathrm{a}}$ & $13,78^{\mathrm{a}}$ & $15,20^{\mathrm{b}}$ & $16,80^{\mathrm{a}}$ \\
\hline & \multicolumn{2}{|c|}{$13,73^{b} \pm 3,42$} & \multicolumn{2}{|c|}{$16,00^{\mathrm{a}} \pm 3,25$} \\
\hline \multirow{2}{*}{$\begin{array}{l}\text { Cell wall thickness } \\
\qquad(\mu \mathrm{m})\end{array}$} & $3,71^{\mathrm{b}}$ & $4,37^{\mathrm{a}}$ & $7,22^{\mathrm{b}}$ & $7,91^{\mathrm{a}}$ \\
\hline & \multicolumn{2}{|c|}{$4,04^{b} \pm 0,82$} & \multicolumn{2}{|c|}{$7,56^{a} \pm 1,54$} \\
\hline \multirow{2}{*}{$\begin{array}{l}\text { Lumen width } \\
\qquad(\mu \mathrm{m})\end{array}$} & $6,37^{\mathrm{a}}$ & $4,95^{\mathrm{b}}$ & $0,76^{\mathrm{b}}$ & $0,98^{\mathrm{a}}$ \\
\hline & \multicolumn{2}{|c|}{$5,66^{a} \pm 2,83$} & \multicolumn{2}{|c|}{$0,87^{b} \pm 0,49$} \\
\hline \multirow{2}{*}{$\begin{array}{l}\text { Vessel width } \\
\qquad(\mu \mathrm{m})\end{array}$} & $142^{\mathrm{b}}$ & $164^{\mathrm{a}}$ & $111^{\mathrm{b}}$ & $121^{\mathrm{a}}$ \\
\hline & \multicolumn{2}{|c|}{$153^{a} \pm 43$} & \multicolumn{2}{|c|}{$116^{\mathrm{b}} \pm 29$} \\
\hline \multirow{2}{*}{$\begin{array}{l}\text { Area of vessels } \\
\qquad\left(\mu \mathrm{m}^{2}\right)\end{array}$} & $16235^{\mathrm{b}}$ & $21179^{a}$ & $10100^{\mathrm{b}}$ & $11619^{a}$ \\
\hline & \multicolumn{2}{|c|}{$18707^{a} \pm 7974$} & \multicolumn{2}{|c|}{$10860^{b} \pm 5007$} \\
\hline \multirow{2}{*}{$\begin{array}{l}\text { Vessels coverage } \\
(\%)\end{array}$} & $8^{b}$ & $9^{a}$ & $13^{\mathrm{b}}$ & $17^{\mathrm{a}}$ \\
\hline & \multicolumn{2}{|c|}{$9^{b} \pm 3$} & \multicolumn{2}{|c|}{$15^{\mathrm{a}} \pm 5$} \\
\hline
\end{tabular}

Different letters indicated significant differences between sections of same species and between species $(p<0,05)$.

\section{Derived wood properties}

Derived values of B. spiciformis and P. angolensis wood properties are shown in Table 2. These derived wood properties are usually used to predict pulp and paper properties through fibre morphology. In papermaking with hardwood fibres, Runkel ratio lower than 1.0 is desirable for a good paper conformability (Dean 1995, Ona et al. 2001, Ohshima et al. 2005, Azeez et al. 2016) due that fibres are considered as thin walled fibres and good mechanical strength properties are usually obtained (Dutt and Tyagi 2011). Both B. spiciformis and $P$. angolensis Runkel ratios are greater than 1,0 which indicates that fibres obtained from this wood species could not be suitable for paper production (Xu et al. 2006), however, an index from 1 to 2 have been considered acceptable for papermaking (de Almeida et al. 2016).

Luce's shape factor is related to paper sheet density (Ona et al. 2001, Ohshima et al. 2005). In 14-year-old E. globulus trees, values reported were between 0,297-0,329 (Ona et al. 2001) and 0,3900,440 (Ohshima et al. 2005). However, both B. spiciformis and P. angolensis Luce's shape factor values are higher than the reported for hardwoods and the reason may be associated with the cell wall thickness, since both fibre width and fibre lumen width are used to obtain the cross-sectional fibre wall area in the equation for Luce's shape factor (Ohshima et al. 2005).

The slenderness ratio is an important parameter related to the physical properties of handsheets such as strength, tear index, burst index and breaking length (Tutus et al. 2015). According to those physical properties, the desirable slenderness ratio is between 70-90 in softwoods and 40-60 in hardwoods (Akgul and Tozluoglu 2009). Hence, the ratio obtained in B. spiciformis and P. angolensis was 65,73 and 59,85 respectively. Slenderness ratio in B. eurycoma have been reported 71,23 (Olufunmilayo 2013), while in Eucalyptus species have been reported between 42-66 (Ona et al. 2001, Ohshima et al. 2005, Dutt and Tyagi 2011). 
Regarding the flexibility coefficient, it has a positive effect on the mechanical strength due to a larger number of bonds between fibres (Dutt and Tyagi 2011). According to Istas et al. (1954) there are four types of fibres classified by the flexibility coefficient: (1) High elastic fibres having flexibility coefficient greater than $75 \%$, (2) elastic fibres having a coefficient between $50-75 \%$, (3) rigid fibres having a coefficient between $30-50 \%$, and (4) high rigid fibres with a coefficient less than $30 \%$. B. spiciformis fibres can be classified as rigid fibres $(41,2 \%)$, while $P$. angolensis showed highly rigid fibres (5,4\%). Olufunmilayo (2013) reported for B. eurycoma a flexibility coefficient of $63 \%$, while Eucalyptus coefficients are between 38 to 74\% (Ona et al. 2001, Dutt and Tyagi 2011). Concerning rigidity coefficient, $P$. angolensis showed the highest value $(47,3 \%)$ which influences negatively the tensile, tear and burst of handsheets (Tutus et al. 2015).

The fibres with low slenderness ratio, high Runkel ratio and low flexibility are expected to have negative effect on pulp mechanical strength, due that short and thick fibres do not readily collapse to ribbons and provide less surface contact for bonding (Dutt and Tyagi 2011). Stiffer and low flexible fibres form bulky paper of lower bonded area, coarse surfaced and contain a large amount of void volume (Dutt and Tyagi 2011). Therefore, according to the derived values reached, the low elasticity fibres should not be used for writing paper production, but may be used for manufacturing boards, cardboards, rigid cardboards or packaging papers (Dutt and Tyagi 2011, Kiaei et al. 2011).

Table 2. Derived wood properties of B. spiciformis and P. angolensis.

\begin{tabular}{|ccc|}
\hline Traits & B. spiciformis & P. angolensis \\
\hline $\begin{array}{c}\text { Runkel ratio } \\
(2 \times \mathrm{CWT} / \mathrm{LW}\end{array}$ & $1,5 \pm 0,4$ & $17,6 \pm 1,9$ \\
\hline $\begin{array}{c}\text { Luce's shape factor } \\
\left(\mathrm{FW}^{2}-\mathrm{LW}^{2}\right) /\left(\mathrm{FW}^{2}+\mathrm{LW}^{2}\right)\end{array}$ & $0,71 \pm 0,09$ & $0,99 \pm 0,001$ \\
\hline $\begin{array}{c}\text { Slenderness ratio } \\
\text { FL/FW }\end{array}$ & $65,7 \pm 0,6$ & $59,9 \pm 4,7$ \\
\hline $\begin{array}{c}\text { Flexibility coefficient (\%) } \\
(\mathrm{LW} / \mathrm{FW}) \times 100\end{array}$ & $41,2 \pm 7,1$ & $5,4 \pm 0,6$ \\
\hline $\begin{array}{c}\text { Rigidity coefficient (\%) } \\
(\mathrm{CWT} / \mathrm{FW}) \times 100\end{array}$ & $29,4 \pm 3,5$ & $47,3 \pm 0,3$ \\
\hline
\end{tabular}

CWT: cell wall thickness, LW: lumen width, FW: fibre width, FL: fibre length.

\section{Chemical composition of wood}

The chemical composition of wood from B. spiciformis and P. angolensis is presented in Table 3. The results showed that existed important differences in the amount of the main components present in both species. The cellulose, holocellulose, alpha-cellulose and acetone-soluble extractives contents, as well as the $\mathrm{S} / \mathrm{G}$ ratio, were higher in B. spiciformis than in $P$. angolensis, while the opposite occurs for hemicelluloses and lignin contents. Interestingly, the $\mathrm{S} / \mathrm{G}$ ratio of $P$. angolensis is very low $(0,89)$ indicating that the lignin of this hardwood species has higher amount of G-type, instead of S-type units, which would worth a more detailed characterization of lignin in this species in a future work. This is remarkable due that high S-type units promote the delignification and decrease recondensation during the kraft pulping, facilitating the delignification and bleaching processes (del Río et al. 2005, Pinto et al. 2005, Carrillo et al. 2017). Therefore, B. spiciformis should show a better performance during alkaline pulping procedures due to its lowest lignin content and highest S-type units amount than $P$. angolensis, in addition to its higher cellulose and alpha-cellulose content. In hardwoods with high pulpability, as E. globulus genotypes, the $\mathrm{S} / \mathrm{G}$ ratio reported is higher (between 2,0-5,5) while lignin and cellulose contents are in agreement with these values (Guerra et al. 2008, Aguayo et al. 2015).

On the other hand, extractives content affects negatively the pulping procedures, causing increased reagents consumption, inhibition reactions of the delignification process, equipment corrosion and 
reduction of the pulp quality (Fengel and Wegener 1989, de Almeida et al. 2016). In both studied species, the extractive content is acceptable, although in commercial E. globulus trees the contents have been reported to be lower $(0,5-3,5 \%)$ (Aguayo et al. 2014, Martínez et al. 2015). However, in softwood species the extractives content is higher than 5\% (de Almeida et al. 2016).

Another noteworthy feature found was for the abundance of some sugars that compose the hemicelluloses. Although the main saccharide found was xylose from the xylans that is a typical hemicellulose found in hardwoods, other minority sugars such as arabinose, mannose, glucose, galactose and rhamnose where significant higher in P. angolensis, which could also have a particular polysaccharide structure in wood. During alkaline pulping, the hemicellulose retention plays an important role related with pulp yield and strength properties (Azeez et al. 2016), and have been associated to the hemicelluloses structure, molar mass, their substitution degree with methylglucoronic acid and alkali stability in different Eucalyptus samples (Martínez et al. 2015, Carrillo et al. 2017). Consequently, as have been observed in another hardwood species, inherent structural features and content of some particular hemicellulose sugars in B. spiciformis and P. angolensis woods may have an influence on the pulpability of these both species. Atuanya and Ibhadode (2011) reported for $B$. nigerica, $44,5 \%$ cellulose content; $20,1 \%$ pentosans; $21,2 \%$ lignin; $2,4 \%$ extractives and $4 \%$ ashes, which can be roughly comparable with the values reported in this study. Lhate et al. (2010) reported the chemical composition of $P$. angolensis sapwood, outer- and inner-heartwood, with $34 \%$ cellulose $12,7 \%$ hemicelluloses $29,8 \%$ lignin and 3,8\% of extractives in sapwood. Cuvilas et al. (2014) reported a lignin content of $34,7 \%$ and extractives of $8,3 \%$ in $P$. angolensis.

Table 3. Chemical composition of wood from B. spiciformis and P. angolensis.

\begin{tabular}{|l|c|c|}
\hline \multicolumn{1}{|c|}{$\begin{array}{c}\text { Components } \\
\text { (\%) }\end{array}$} & B. spiciformis & P. angolensis \\
\hline Cellulose & $50,1^{\mathrm{a}} \pm 1,07$ & $41,9^{\mathrm{b}} \pm 2,12$ \\
\hline Hemicelluloses & $17,6^{\mathrm{b}} \pm 0,78$ & $26,5^{\mathrm{a}} \pm 2,19$ \\
\hline Arabinose & $0,04^{\mathrm{b}} \pm 0,07$ & $1,04^{\mathrm{a}} \pm 0,27$ \\
\hline Mannose & $0,36^{\mathrm{b}} \pm 0,08$ & $1,24^{\mathrm{a}} \pm 0,09$ \\
\hline Xylose & $12,45^{\mathrm{b}} \pm 0,05$ & $14,58^{\mathrm{a}} \pm 0,09$ \\
\hline Glucose & $0,11^{\mathrm{b}} \pm 0,07$ & $3,38^{\mathrm{a}} \pm 0,35$ \\
\hline Galactose & $0,09^{\mathrm{b}} \pm 0,07$ & $1,37^{\mathrm{a}} \pm 0,14$ \\
\hline Rhamnose & $0,04^{\mathrm{b}} \pm 0,08$ & $1,28^{\mathrm{a}} \pm 0,28$ \\
\hline Uronic groups & $4,52^{\mathrm{a}} \pm 0,64$ & $3,58^{\mathrm{b}} \pm 1,06$ \\
\hline Acetone/water extractives & $5,6^{\mathrm{a}} \pm 0,24$ & $4,6^{\mathrm{a}} \pm 0,95$ \\
\hline Lignin & $22,5^{\mathrm{b}} \pm 0,7$ & $29,2^{\mathrm{a}} \pm 0,22$ \\
\hline Holocellulose & $68,0^{\mathrm{a}} \pm 0,37$ & $67,7^{\mathrm{a}} \pm 1,09$ \\
\hline Alpha-cellulose & $49,3^{\mathrm{a}} \pm 1,8$ & $40,0^{\mathrm{b}} \pm 1,58$ \\
\hline Lignin S/G ratio & $1,72^{\mathrm{a}} \pm 0,07$ & $0,89^{\mathrm{b}} \pm 0,08$ \\
\hline
\end{tabular}

Different letters indicate significant differences between species $(p<0,05)$.

\section{Kraft pulping}

Kraft pulping of wood chips from B. spiciformis and P. angolensis was performed at an $\mathrm{H}$-factor of 800 and different active alkali charges $(14 \%$ to $25 \%)$ with the aim to obtain bleachable-grade pulps (Figure 2A). For the most common hardwood species used to produce bleached pulps, such as Eucalyptus, acacia or birch, active alkali charges of $16 \%-24 \%$ are usually enough to generate bleachable-grade pulps with kappa number around 16-19 and pulp yield of 50-55\% (Pinto et al. 2005, Aguayo et al. 2010). In the present case, for both species, the demand of active alkali was higher (up to $25 \%$ ) and pulps with high kappa number (24 for B. spiciformis and 27 for $P$. angolensis) were obtained, at the cost of a lower screened pulp yield (approximately $40 \%$ ) for both species (Figure $2 \mathrm{~B}$ ). $P$. angolensis was harder to pulping than $B$. spiciformis since it presented higher kappa number during cooking at different alkali charges, associated with lower pulping yield (Figure 2A and Figure 2B, 
respectively). The main factors that affect the lower pulpability of $P$. angolensis could be related with the anatomical features. High-density woods (more than $600 \mathrm{~kg} \mathrm{~m}^{-3}$ ) are usually associated with tylosis formation or extractives deposition in lumens that lead to an irregular delignification of wood chips. Which is mainly due to the poor efficiency of the impregnation with the cooking liquors (Ramírez et al. 2009). Anatomically, P. angolensis wood also presented occluded fibre lumen, which can represent an important drawback for reagent diffusion during pulping procedures. Chemical features such as, extractives amount, lignin content and $\mathrm{S} / \mathrm{G}$ ratio are also known to affect the delignification rate and alkali consumption. As already mentioned, $P$. angolensis showed the higher lignin content and higher G-type units (Table 2). G-type lignin contains more resistant linkages than S-type units, making lignin less reactive and resistant to chemical degradation (Boerjan et al. 2003, Pinto et al. 2005, del Río et al. 2005, Rencoret et al. 2008).
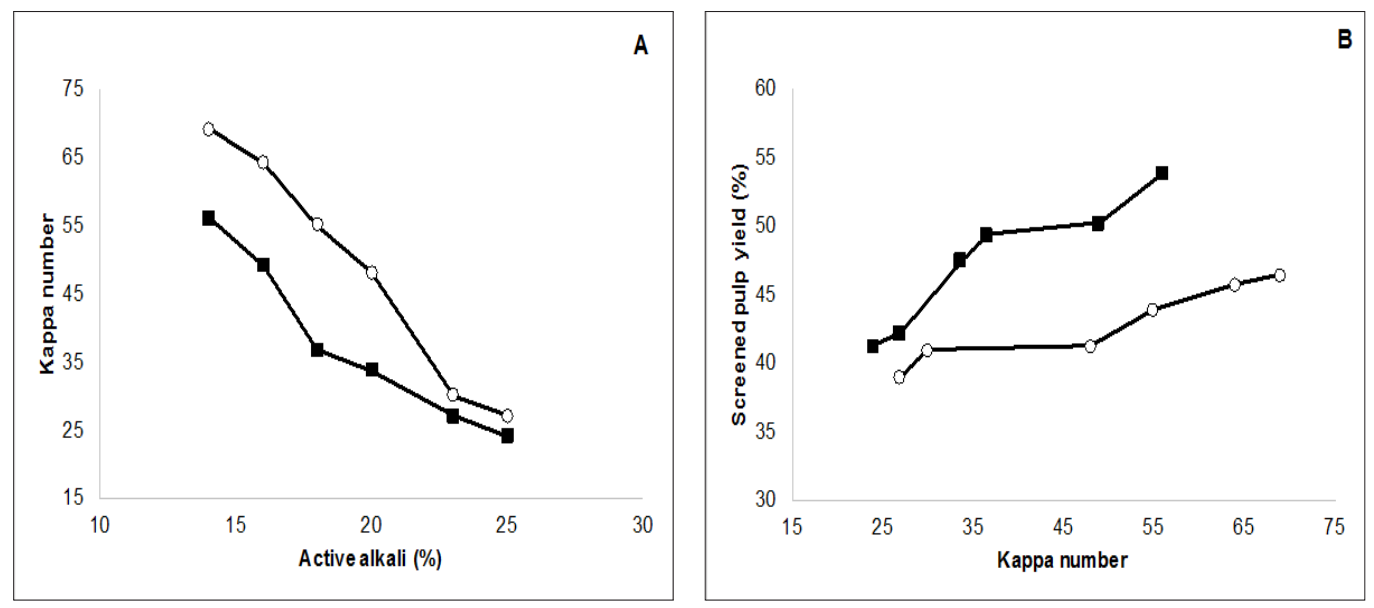

Figure 2. (A) Kappa number and (B) delignification selectivity after kraft pulping of B. spiciformis (-m-) and P. angolensis (-O-).

Unbleached kraft pulps were refined at 2500 and 5000 revolutions in a PFI mill to increase internal and external fibrillation of pulp (Figure 3A). Only B. spiciformis was able to be refined at values higher than $20^{\circ} \mathrm{SR}$ (usually required for high strength papers) achieving $24^{\circ} \mathrm{SR}$ at $5000 \mathrm{rpm}$. P. angolensis was harder to refine and only poor fibrillation was obtained at $5000 \mathrm{rpm}\left(10^{\circ} \mathrm{SR}\right)$. The main reason of the poor fibrillation of $P$. angolensis may be related with the morphological features of its fibres. As was mentioned, its highest cell wall thickness and occluded lumen contribute to the decreasing of fibres elasticity (Runkel ratio of 17,6 and flexibility coefficient of 5,4\%), demonstrating that stiff fibres are harder to refine and process. Figure 3B, Figure 3C and Figure 3D shows the strength properties of $B$. spiciformis and $P$. angolensis pulps. Tensile, tear and burst indexes of $100,3 \mathrm{Nm} \mathrm{g}^{-1} ; 10,7 \mathrm{mN}^{-\mathrm{m}^{2} \mathrm{~g}^{-1} \text { and }}$ $6,1 \mathrm{kPa} \cdot \mathrm{m}^{2} \mathrm{~g}^{-1}$, respectively, were reached for B. spiciformis pulps after refining at 5000 revolutions. The pulps of $P$. angolensis after refining at 5000 revolutions reached tensile, tear and burst indexes of $99,6 \mathrm{Nm} \mathrm{g}^{-1} ; 5,9 \mathrm{mN} \cdot \mathrm{m}^{2} \mathrm{~g}^{-1}$ and $4,9 \mathrm{kPa} \cdot \mathrm{m}^{2} \mathrm{~g}^{-1}$, respectively. As was already discussed, the lowest strength properties of $P$. angolensis were expected, mainly due to the influence of the low slenderness ratio and flexibility coefficients, and high Runkel ratio of its fibres (Table 2). As a reference of strength properties in commercial hardwoods, Guerra et al. (2008) reported for kraft E. globulus pulps tensile indexes of 66-102 $\mathrm{Nm} \mathrm{g}^{-1}$, tear indexes of 6-9 mN. $\mathrm{m}^{2} \mathrm{~g}^{-1}$ and burst indexes 5-8 $\mathrm{kPa} \cdot \mathrm{m}^{2} \mathrm{~g}^{-1}$. 

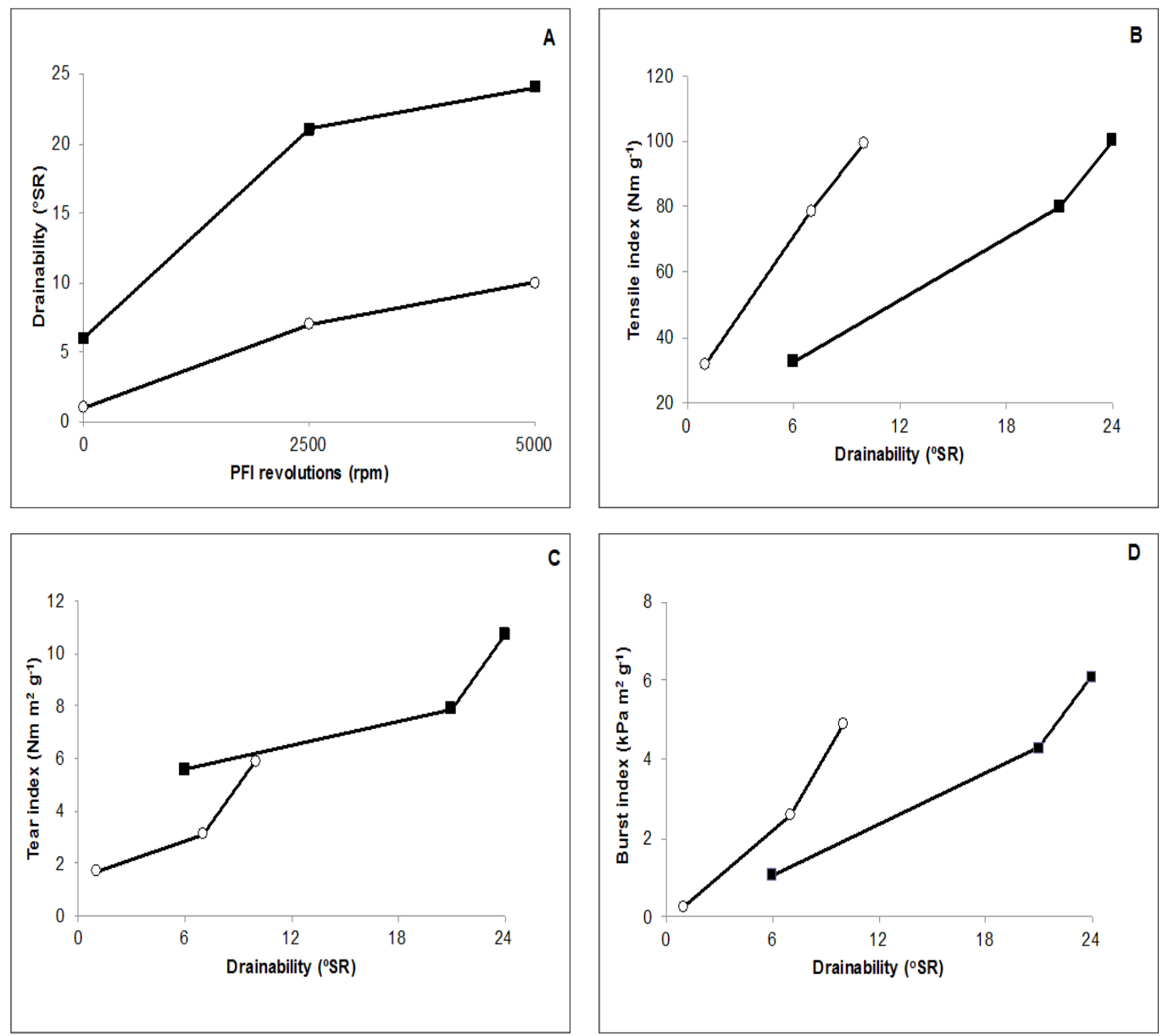

Figure 3. (A) Drainabiity and pulp strength properties of B. spiciformis (-m-) and P. angolensis (-O). (B) Tensile index, (C) tear index and (D) burst index.

In Table 4 are shown some biometric properties of pulp fibres after the refining process as fibre length, coarseness, fines content and kink index. Fibre length is an important descriptor factor of pulp quality, due to its influence to paper strength properties (Ek et al. 2009). Fines content is related with amount of short and thin cells as parenchyma cells and broken fibres, and have been reported that it influences positively the sheet tensile index (Retulainen 1997). The kink index refers to a deformation on the fibre that can be a weak or a breaking point; while coarseness, defined as fibre mass per fibre length, is a good index for predicting pulp properties of fibres and basic density of wood (Via et al. 2004, Mansfield and Weineisen 2007, Carrillo et al. 2015). The fibre length and coarseness of both species decreases after refining, while kink index and fines content increases. These results are expected considering that during refining some fibres are more likely to bend and break, increasing the fines release and kink index of pulp fibres. Particularly, $P$. angolensis pulps showed the higher values for fibre length, fines content and coarseness, and lower values for kink index during the different refining steps, which is probably due to its higher fibre cell wall thickness. However, despite the physical features of pulp fibres, B. spiciformis showed better strength pulps properties than $P$. angolensis, which could be considered unexpected according to pulp fibres features. Nevertheless, very-high coarseness and very-high cell wall thickness values can lead to poor conformability and low fibre-to-fibre contact in sheets (Dean 1995), which resulted in poor derived wood properties and low strength properties as in $P$. angolensis. 
Table 4. Fibre biometry of $B$. spiciformis and $P$. angolensis pulps.

\begin{tabular}{|c|c|c|c|c|c|c|}
\hline & \multicolumn{3}{|c|}{ B. spiciformis } & \multicolumn{3}{c|}{ P. angolensis } \\
\hline & \multicolumn{3}{|c|}{ PFI revolutions (rpm) } & \multicolumn{3}{c|}{ PFI revolutions (rpm) } \\
\hline & 0 & 2500 & 5000 & 0 & 2500 & 5000 \\
\hline $\begin{array}{c}\text { Fibre length } \\
(\mathbf{m m})\end{array}$ & $1,02^{\mathrm{a}}$ & $0,93^{\mathrm{b}}$ & $0,92^{\mathrm{b}}$ & $0,98^{\mathrm{a}}$ & $0,97^{\mathrm{a}}$ & $0,95^{\mathrm{b}}$ \\
\hline Coarseness & $\pm 0,01$ & $\pm 0,01$ & $\pm 0,01$ & $\pm 0,01$ & $\pm 0,01$ & $\pm 0,01$ \\
$(\mathbf{m g} / \mathbf{1 0 0} \mathbf{m})$ & $\pm 1,1$ &, $\pm 3^{\mathrm{a}}$ & $6,9^{\mathrm{c}}$ & $11,5^{\mathrm{a}}$ & $11,2^{\mathrm{a}}$ & $10,6^{\mathrm{b}}$ \\
\hline \multirow{2}{*}{ Kink index } & $0,90^{\mathrm{b}}$ & $1,92^{\mathrm{a}}$ & $2,40^{\mathrm{a}}$ & $0,58^{\mathrm{b}}$ & $0,72^{\mathrm{b}}$ & $1,34^{\mathrm{a}}$ \\
& $\pm 0,03$ & $\pm 0,01$ & $\pm 0,42$ & $\pm 0,08$ & $\pm 0,03$ & $\pm 0,03$ \\
\hline Fines content & $2,9^{\mathrm{b}}$ & $3,2^{\mathrm{b}}$ & $5,7^{\mathrm{a}}$ & $2,5^{\mathrm{c}}$ & $6,7^{\mathrm{b}}$ & $8,3^{\mathrm{a}}$ \\
$(\mathbf{\%})$ & $\pm 1,05$ & $\pm 0,01$ & $\pm 0,07$ & $\pm 0,07$ & $\pm 0,21$ & $\pm 0,28$ \\
\hline
\end{tabular}

Different letters indicate significant differences between refined pulps of the same specie $(p<0,05)$.

\section{CONCLUSIONS}

P. angolensis and B. spiciformis are species acknowledged by their heavy and hard wood properties. However, $P$. angolensis wood has higher wood density, higher fibre width and cell wall thickness, and an occluded fibre lumen as remarkable anatomical properties. Regarding chemical features, $B$. spiciformis has a higher cellulose content, lower hemicellulose and lignin content, and higher $\mathrm{S} / \mathrm{G}$ ratio than $P$. angolensis. The kraft pulping procedure of both species required higher alkali charges to achieve bleaching grade pulps, resulting in low pulp yield and high kappa number. The pulps obtained from $P$. angolensis wood were harder to refine and showed lower strength properties than B. spiciformis, which was attributed to the very-high values obtained for biometric properties and not adequate derived wood properties of wood and pulp fibres of $P$. angolensis, as wood density, cell wall thickness, Runkel ratio, slenderness ratio, flexibility coefficient and coarseness. It is concluded that $B$. spiciformis wood has better pulpability than $P$. angolensis wood, according to its pulps properties, despite of the similar pulp yield between both species. $B$. spiciformis and $P$. angolensis may be not suitable for high quality papers, but both species could be useful for unbleached wrapping paper and rigid cardboards.

\section{ACKNOWLEDGMENTS}

To the International Chilean Agency of Cooperation for Development (AGCID) that provided funding for this study through a Nelson Mandela Scholarship. A special thanks to the "Faculdade de Ciências Agrárias, Universidade José Eduardo dos Santos", Angola.

\section{REFERENCES}

Abbot, P.G.; Lowore, J.D. 1999. Characteristics and management potential of some indigenous firewood species in Malawi. Forest Ecology and Management 119: 111-121. 
Afe, A.J. 2016a. Comparative studies of the chemical nature of ethanol product of selected wood species. Forest Research 5: 185.

Afe, A.J. 2016b. Examination of chemical properties of ethanol product of Brachystegia eurichoma wood. Forest Research 5: 186.

Aguayo, M.G.; Ferraz, A.; Elissetche, J.P.; Masarin, F.; Mendonça, R.T. 2014. Lignin chemistry and topochemistry during kraft delignification of Eucalyptus globulus genotypes with contrasting pulpwood genotypes with contrasting pulpwood characteristics. Holzforschung 68: 623-629.

Aguayo, M.G.; Ruiz, J.; Norambuena, M.; Mendonça, RT. 2015. Structural features of dioxane lignin from Eucalyptus globulus and their relationship with the pulp yield of contrasting genotypes. Maderas. Ciencia y Tecnología 17: 625-636.

Aguayo, M.G.; Quintupill, L.; Castillo, R.; Baeza, J.; Freer, J.; Mendonça, R.T. 2010. Determination of differences in anatomical and chemical characteristics of tension and opposite wood of 8-year old Eucalyptus globulus. Maderas. Ciencia y Tecnología 12: 241-251.

Akgul, M.; Tozluoglu, A. 2009. Some chemical and morphological properties of juvenile woods from Beech (Fagus orientalis L.) and Pine (Pinus nigra A.) plantations. Trends in Applied Sciences Research. 4: 116-125.

Ali,A.C.; Uetimane, J.E.; Lhate, I.A.; Terziev, N. 2008. Anatomical characteristics, properties and use of traditionally used and lesser-known wood species from Mozambique: a literature review. Wood Science and Technology 42: 453-472.

Atuanya, C.U.; Ibhadode, A.O.A. 2011. Characterization of okhuen (Brachystegia nigerica) wood as a potential reinforcement for polymer composites. International Journal of Engineering \& Technology 11: 116004-7272.

Azeez, M.A.; Andrew, J.E.; Sithole, B.B. 2016. A preliminary investigation of Nigerian Gmelina arborea and Bambusa vulgaris for pulp and paper production. Maderas. Ciencia y Tecnología. 18: 65-78.

Boerjan, W.; Ralph, J.; Baucher, M. 2003. Lignin biosynthesis. Annual Review of Plant Biology. 54: 519-546.

Carballo, A.L.R.; Orea, I.U.; Cordero, M.E. 2004. Composición química de tres maderas en la provincia del Pinar del Río, Cuba. Revista Chapingo. Serie Ciencias Forestales y del Ambiente 10: $57-62$.

Carrillo, I.; Aguayo, M.G.; Valenzuela, S.; Mendonça, R.T.; Elissetche, J.P. 2015. Variations in wood anatomy and fiber biometry of Eucalyptus globulus genotypes with different wood density. Wood Research 60: 1-10.

Carrillo, I.; Vidal, C.; Elissetche, J.P.; Mendonça, R.T. 2017. Wood anatomical and chemical properties related to the pulpability of Eucalyptus globulus: a review. Southern Forests 1-8.

Chen, C. 1992. Nitrobenzene and cupric oxide oxidations. In: Methods in lignin chemistry. Lin, S.Y.; Dence, C.W. (eds.), Methods in lignin chemistry. Berlin: Springer-Verlag.

Cuvilas, C.; Lhate, I.; Jirjis, R.; Terziev, N. 2014. The characterization of wood species from Mozambique as a fuel. Energy Sources, Part A: Recovery, Utilization, and Environmental Effects 36: $851-857$.

de Almeida, C.C.F.; Rios, P.D.; da Cunha, A.B.; Ampessan, C.G.M.; Spanhol, A. 2016. Applicability evaluation of Cupressus lusitanica for pulp production. Maderas. Ciencia y Tecnología 18: $651-662$.

Dean, G.H. 1995. Objectives for wood fibre quality and uniformity. In: Potts, B.M.; Borralho, N.M.G.; Reid, J.B.; Cromer, R.N.; Tibbits, W.N.; Raymond, C.A. (eds), Eucalypts plantations: 
improving fibre yield and quality. CR-IUFRO Conference. 19-24 February, Hobart, Australia.

del Río, J.C.; Gutiérrez, A.; Hernando, M.; Landín, P.; Romero, J.; Martínez, A.T. 2005. Determining the influence of eucalypt lignin composition in paper pulp yield using Py-GC/MS. Journal of Analytical and Applied Pyrolysis 74: 110-115.

Delgado-Matas, C.; Pukkala, T. 2012. Growth and yield of nine species in Angola. Journal of Forestry Research. 23: 197-204.

Dutt, D.; Tyagi, C.H. 2011. Comparison of various eucalyptus species for their morphological, chemical, pulp and paper making characteristics. Indian Journal of Chemical Technology 18: 145-151.

Ek, M.; Gellerstedt, G.; Henriksson, G. 2009. Pulp and paper chemistry and technology. Vol. 1. Wood chemistry and wood biotechnology. Berlin: GmbH \& Co. KG. Gruyter.

Fengel, D.; Wegener, G. 1989. Wood: Chemistry, Ultrastructure, Reactions. Berlin. Walter de

Figueiredo, E.; Smith, G.F.; César, J. 2009. The flora of Angola: first record of diversity and endemism. Taxon 58: 233-236.

Frost, P. 1996. The ecology of miombo woodlands. In: Campbell, B. (eds). The miombo in transition: Woodlands and welfare in Africa. Center for International Forestry Research. Bogor, Indonesia.

Grundy, I.M. 2006. Age determination of Miombo species Brachystegia spiciformis (LeguminosaeCaesalpinoideae) in Zimbabwe using growth rings. Southern African Forestry Journal 206: 5-12.

Guerra, A.; Elissetche, J.P.; Norambuena, M.; Freer, J.; Valenzuela, S.; Rodríguez, J.; Balocchi, C. 2008. Influence of lignin structural features on Eucalyptus globulus kraft pulping. Industrial \& Engineering Chemistry Research 47: 8542-8549.

Heinrichs, J.F.; Lassen, L.E. 1970. Improved technique for determining the volume of irregularly shaped wood blocks. Forest Products Journal 20(4): 24

Hudson, I.; Wilson, L.; Van Beveren, K. 1998. Vessel and fibre property variation in Eucalyptus globulus and Eucalyptus nitens: some preliminary results. IAWA Journal 19: 111-130.

Hus, S.; Tank, T.; Gosksal, E. 1975. Considering eucalyptus (E. camaldulensis Dehnh.) wood which grows in Turkey (in Tarsus-Karabacak), Morphology and opportunity for evaluating semi chemical cellulose in paper industry, Tubitak publication, USA.

Istas, J.R.; Heremans, R.; Roekelboom, E.L. 1954. Caracteres generaux de bois feuillus du Congo Belge en relation avec leur utilization dans I'industrie des pates a papier: Etude detaillee de quelques essences. Gembloux: INEAC (Serie Technique, No. 43).

Kiaei, M.; Samariha, A.; Kasmani, E. 2011. Characterization of biometry and the chemical and morphological properties of fibers from bagasse, corn, sunflower, rice and rapeseed residues in Iran. African Journal of Agricultural Research. 6: 3762-3767.

Leal, S.; Pereira, H.; Grabner, M.; Wimmer, R. 2003. Clonal and site variation of vessels in 7-year-old Eucalyptus globulus. IAWA Journal 24: 185-195.

Lhate, I.; Cuvilas, C.; Terziev, N.; Jirjis, R. 2010. Chemical composition of traditionally and lesser used wood species from Mozambique. Wood Material Science and Engineering 5: 143-150.

Louppe, D.; Oteng-Amoako, A.A.; Brink, M. 2008. Plant resources of tropical Africa (7) 1. Timbers 1. PROTA Foundation. Wageningen. Netherlands. Backhuys Publishers, Leiden.

Luce, G.E. 1970. The physics and chemistry of wood pulp fibers. In: STAP No. 8, TAPPI, New York. 
Mansfield, SD.; Weineisen, H. 2007. Wood fibre quality and kraft pulping efficiencies of trembling aspen (Populus tremuloides michx.) clones. Journal of Wood Chemistry and Technology 27: 135-151.

Martínez, P.; Pereira, M.; Mendonça, R.T. 2015. Retention and structure of xylans from Eucalyptus globulus genotypes with different pulpwood characteristics. Journal of Wood Chemistry and Technology 35: 129-136.

Mendonça, R.T.; Jara, J.F.; González, V.; Elissetche, J.P.; Freer, J. 2008. Evaluation of the white-rot fungi Ganoderma australe and Ceriporiopsis subvermispora in biotechnological applications. Journal of Industrial Microbiology \& Biotechnology 35: 1323-1330.

Ministério da Agricultura Desenvolvimento Rural e das Pescas, MINADERP. 2011. Perfil florestal de Angola. Jornada técnica científica sobre florestas e seguranca alimentar em Angola. 30-28 September, Luanda, Angola.

Miranda, I.; Pereira, H. 2002. Variation of pulpwood quality with provenances and site in Eucalyptus globulus. Annals of Forest Science 59: 283-291.

Noah, A.S.; Abiola, J.K.; Ayeni, O.D.; Bamidele, O.D. 2014. Comparative assessment of selected acoustic properties of talking drums made from wood of Gmelina arborea (Roxb) and Brachystegia eurycoma (Harms). Journal of Multidisciplinary Engineering Science and Technology 5:1.

Ohshima, J.; Yokota, S.; Yoshizawa, N.; Ona, T. 2004. Within-tree variation of detailed fiber morphology and its position representing the whole-tree value in Eucalyptus camaldulensis and Eucalyptus globulus. In: Ona, T. (eds). Improvement of Forest Resources for Recyclable Forest Products. Springer Japan.

Ohshima, J.; Yokota, S.; Yoshizawa, N.; Ona, T. 2005. Examination of within-tree variations and the heights representing whole-tree values of derived wood properties for quasi-non-destructive breeding of Eucalyptus camaldulensis and Eucalyptus globulus as quality pulpwood. Journal of Wood Science 51:102-111.

Olufemi, B. 2012. Yield and mechanical properties of veneer from Brachystegia nigerica. Journal of Forestry Research 23: 295-298.

Olufunmilayo, O.D. 2013. Determination of pulp and paper making suitability indices of some Nigerian species Leguminosae: Caesalpinoideae. Academic Journal of Interdisciplinary Studies. 13: $61-68$

Ona, T.; Sonoda, T.; Ito, K.; Shibata, M.; Tamai, Y.; Kojima, K.; Ohshima, J.; Yokoys, S.; Yoshizawa, N. 2001. Investigation of relationships between cell and pulp properties in Eucalyptus by examination of within-tree property variations. Wood Science and Technology. 35: 229-243. Ltd.

Palgrave, M.C. 2002. (eds). Trees of Southern Africa. Cape Town. Random House Struik (Pty)

Pinto, P.C.; Evtuguin, D.V.; Neto, C.P. 2005. Effect of structural features of wood biopolymers on hardwood pulping and bleaching performance. Industrial \& Engineering Chemistry Research 44: 9777-9784.

Quilhó, T.; Miranda, I.; Pereira, H. 2006. Within-tree variation in wood fibre biometry and basic density of the urograndis eucalypt hybrid (Eucalyptus grandis $\times$ Eucalyptus urophylla). IAWA Journal 27: $243-254$.

Ramírez, M.; Rodriguez, J.; Balocchi, C.; Peredo, M.; Elissetche, J.P.; Mendonça, R.; Valenzuela, S. 2009. Chemical composition and wood anatomy of Eucalyptus globulus clones: variations and relationships with pulpability and handsheet properties. Journal of Wood Chemistry and Technology 29: 43-58.

Rencoret, J.; Marques, G.; Gutiérrez, A.; Ibarra, D.; Li, J.; Gellerstedt, G.; Santos, J.I.; Jiménez-Barbero, J.; Martínez, A.T.; del Río, J.C. 2008. Structural characterization of milled wood 
lignin from different eucalypt species. Holzforschung 62: 514-526.

Retulainen, E. 1997. The role of fibre bonding in paper properties. Reports Series A7, Helsinki University of Technology, Laboratory of Paper Technology, Espoo, Finland.

Runkel, R.O.H. 1949. Über die Herstellung von Zellstoff aus Holz der Gattung Eucalyptus und Versuche mit zwei unterschiedlichen Eucalyptusarten. Das Papier 3: 476-490.

Sangumbe, L.M.V.; Pereira, E.A. 2014. Recovery of degraded areas of training of Miombo with exotic species of Eucalyptus sp and Pinus sp in Huambo. Revista Forestal Baracoa 33: 566-573.

Silva, M.L. 1971. Algunas notas sobre a cultura do eucalipto em Angola. I.I.A.A. Serie Técnica Nova Lisboa $\mathrm{N}^{\circ}$ 24. Instituto de Investigacao Agronómica de Angola.

Sundberg, A.; Sundberg, K.; Lillandt, C.; Holmbom, B. 1996. Determination of hemicelluloses and pectins in wood and pulp fibres by acid methanolysis and gas chromatography. Nordic Pulp and Paper Research Journal 226: 216-219.

Trouet, V.; Haneca, K.; Coppin, P.; Beeckman, H. 2001. Tree ring analysis of Brachystegia spiciformis and Isoberlinia tomentosa: evaluation of the enso-signal in the Miombo woodland of eastern Africa. IAWA Journal 22: 385-399.

Tutus, A.; Kazaskerglu, Y.; Cicekler, M. 2015. Evaluation of tea wastes in usage pulp and paper production. BioResources 10: 5407-5416.

Uetimane, J.E.; Terziev, N.; Daniel, G. 2009. Wood anatomy of three lesser known species from Mozambique. IAWA Journal 30: 277-291.

Via, B.K.; Stine, M.; Shupe, T.; So, C.H.; Groom, L. 2004. Genetic improvement of fiber length and coarseness based on paper product performance and material variability - A review. IAWA Journal 25: 401-414.

Wangaard, F.F. 1962. Contributions of hardwood fibers to the properties of kraft pulps. TAPPI 45: 548-556.

Xu, F.; Zhong, X.C.; Sun, R.C.; Lu, Q. 2006. Anatomy, ultrastructure, and lignin distribution un cell wall of Caragna Korshinskii. Industrial Crops and Products. 24: 186-193.

Yokoyama, T.; Kadla, J.F.; Chang, H.M. 2002. Microanalytical method for the characterization of fibre components and morphology of woody plants. Journal of Agricultural and Food Chemistry 50: $1040-1044$. 